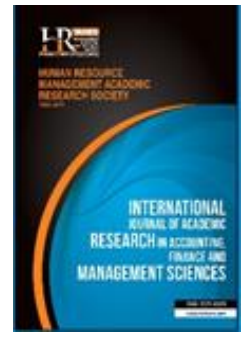

International Journal of Academic Research in Accounting, Finance and Management Sciences

Vol. 10, No.2, April 2020, pp. 264-269

E-ISSN: 2225-8329, P-ISSN: 2308-0337

(C) 2020 HRMARS

www.hrmars.com

To cite this article: Zahri, M. A., Awang, N. Norbahiyah Awang, N. (2020). The Operation of Islamic Trust Funds: A Case Study of CIMB-Principal Asset Management, International Journal of Academic Research in Accounting, Finance and Management Sciences 10 (2):264-269.

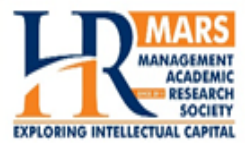

\title{
The Operation of Islamic Trust Funds: A Case Study of CIMB-Principal Asset Management
}

\author{
Mohd. 'Adli Zahri', Norafzan Awang ${ }^{2}$, Norbahiyah Awang ${ }^{3}$ \\ ${ }^{1}$ Operation Division BUJ Technology Enterprise Sdn. Bhd. Malaysia \\ ${ }^{2}$ Faculty of Economic and Management, University College Bestari, Setiu, Terengganu, Malaysia, \\ ${ }^{2}$ Email: afzan@ucbestari.edu.my \\ ${ }^{3}$ Faculty of Computer Science and Mathematics, UiTM, Malaysia
}

\begin{abstract}
This paper aims to discuss the basic understanding of Islamic Trust Fund (ITF) and to analyze performance by evaluating the funds that are managed by the Fund Manager, namely CIMB Principal Asset Management. This paper also to compare the performance of fund returns against market returns. Kuala Lumpur Composite Index is used as market returns benchmark. The findings showed the ITF returns exceeded market returns within three years, and in the years later. Therefore, investors have the opportunity to get higher returns from investing in trust funds, especially in the ITF by using the right investment plan.

Key words Islamic Trust Fund (ITF), Sharia-Compliant, Performance, Mutual Fund, Fund Manager.

$\begin{array}{rrr}\text { Received: } & 10 \text { Jul } 2020 & \text { C The Authors } 2020 \\ \text { Revised: } & 01 \text { Aug } 2020 & \text { Published by Human Resource Management Academic Research Society (www.hrmars.com) } \\ \text { Accepted: } & 15 \text { Aug } 2020 & \begin{array}{l}\text { This article is published under the Creative Commons Attribution (CC BY 4.0) license. Anyone may } \\ \text { reproduce, distribute, translate and create derivative works of this article (for both commercial and } \\ \text { non-commercial purposes), subject to full attribution to the original publication and authors. The full } \\ \text { terms of this license may be seen at: http://creativecommons.org/licences/by/4.0/legalcode }\end{array}\end{array}$
\end{abstract}

\section{Introduction}

In Malaysia, investment in Islamic Trust Funds (ITF) began on January $12^{\text {th }}, 1993$, with the launch of the Trust Fund Ittikal Arab Malaysia, which was managed by Arab-Malaysia Unit Trust Berhad (now known as Am Investment Services Berhad). From 2006 to 2015, Islamic Trust funds have received encouraging responses from the public, seeing from the increase in the number of funds and offers generated from the management of these funds. It was seen clearly from the number of clear values of approved assets which had multiplied five times from RM 9.10 billion in 2006 to RM 52.12 billion in 2015 (Zahri, 2016).

However, despite the encouraging development of the trust funds in these modern economic times, there are still matters that are deemed to be incompliant with the rules of Islamic muamalah (Wan Azman Wan Hassan, 2002). It is important to ensure that these Islamic funds should only be an investment within the halal and secured portfolios that are rooted in Islamic principle (Mansor \& Sulaiman, 2009). Until now, there are questions that are still lingering among scholars. Is the management of the ITF still based on Islamic principle? How does the ITF operate in terms of the applied Shariah principle? What are the criteria for the Shariah factors for the secured investment bodies?

This paper aims to discuss the Shariah principles and the current criteria for Shariah in Islamic funds and to look into the performance of Islamic trust funds under CIMB Principal Asset Management Berhad. This paper is categorised into several subtopics, starting with the introduction, the operation of Islamic 
Trust Funds, CIMB Principal Asset Management Berhad as a case study, the analysis of funds in CIMB Principal Asset Management Berhad and conclusion.

\section{Literature review}

\subsection{The Operation of Islamic Trust Funds}

a) The Principles of Shariah in Islamic Trust Fund

The application of the Shariah Principle in the management of the stocks under Islamic Funds is the determining point of the status of a trust fund. Also, the applied Shariah principles are what differentiate between an Islamic Trust Fund and other conventional trust funds. Among the complied Shariah principle are:

i) Al-Musyarakah. Generally, the stock under Islamic Trust Fund must apply the principle of almusyarakah. This means that every unit holder will share the accumulative value of the funds and everyone possesses a share in the trust fund. Therefore, once a person bought a unit in the trust find, he or she shares the possession of the trust funds with other unit holders (Mansor \& Sulaiman, 2009).

ii) Al-Wakalah. In general, Al-Wakalah means authorisation. In linguistics terms, it contains two definitions, 'representation' and 'authorisation'. In terms of fuquha', al-wakalah means authorising two forms of power to manage matters under their power and knowledge. Besides, al-wakalah is an aqad, or a legal binding that authorise the agent to exercise their duties on behalf of the unitholders. Based on the agreement stipulated in the trust deed, the fund manager is the representative of the unitholders, and he or she is responsible for managing the trust fund. The unitholders will put their full trust to the company that manages their funds, and to represent them in making any investment in various portfolios.

iii) Al-Ujr. Al-Ujr means commissions or fee charged. In Islamic Trust Investment, the fund manager is responsible for managing the funds and investing the funds in various portfolios. In delivering these responsibilities, the company that manages these funds will receive management fees under the concept of al-ujr. More precisely, al-ujr refers to fees and commissions that the customers pay for the services provided.

iv) Musya Properties. Funds investment is regarded as selling properties under the category of Musya Property. Musya properties refer to property that is shared with others who cannot be dividing, and every holder can manage their share with waiting for consent from other holders, under the condition that the portion of the properties has been valued prior. The criteria of investments that are based on the accumulation of investments from various companies that operates in various activities are what truly complied with the concept of musya properties in Islamic principles.

v) 'Uqud Ghayr Musamma. 'Uqud Ghayr Musamma (denominated contact) refers to the aqad that is made to be compatible with the current needs of the times and places. Some of the contracts within this category are bay al-istina' and bay al-wafa'. This means that the concepts of the current modern companies that operate their trust investment based on the contract of 'uqud ghayr musamma', has been publicly accepted and it has been the norm ('urf) to practice. In other words, it is a newly formed contract that was conceived to fulfil the current needs. In fiqh muamalat, these contracts are called 'uqud ghayr musamma' as there were not mentioned in nas (as in the Quran or Hadith) and they were not formally termed by past fukaha' (scholars).

Currently, the ITFs are developing at rapid speed. As a response to the rapid development, various issues regarding ITFs have been discussed and sanctioned by Shariah Advisory Council (SAC), Securities Commission Malaysia (SC) in their series of meetings. From the year of 2012 to 2014, there has been an update to the existing rule underlined in the book 'The Resolutions of the SC Shariah Advisory Council (Second Edition).

Among the addition are; (1) Ta'widh. Ta'widh (compensation) is applied in the Islamic trust fund. It refers to the compensation granted to the creditors (investors) upon agreement between the contracting party when a debtor (supplier) failed or late in delivering his or her obligation to repay a developed debt. (2) $I b r a^{\prime} . I b r a^{\prime}$ is referred to as an action of a person to withdraw the rights and claims to another party, either partially or fully. As a result of Ibra', (the latter) is free from any obligation or liability to the first party (the former).

b) The Shariah criteria for the listed Shariah-Compliant Securities 
The decision to grant the status of Shariah-compliant to any securities is based on the deliberation made by the SAC through two approaches, the quantitative approach and the qualitative approach. For the qualitative approach, the SAC takes into account the qualitative aspect, which involves public perception of the company's activities from the Islamic perspective. For the quantitative approach, the SAC adopts a twotier system, which applies: (i) business activity benchmarks and (ii) financial ratio benchmarks (Securities Commission Malaysia, 2019). A benchmark of less than 5\% applies to Sharia non- compliant businesses or activities, such as conventional banking. The $5 \%$ benchmark includes conventional banking; conventional insurance; gambling, alcohol and pork-related activities; non-halal food and beverages; Sharia noncompliant entertainment; tobacco and related activities; benefit income from conventional accounts and instruments (including dividends from investments in Sharia non-compliant instruments and interest income received as a result of a court or arbitrator's decision); and other activities that are considered Sharia non-compliant. For those businesses/activities, the contribution from Sharia non- compliant businesses/activities to the group's earnings or the group's pre-tax profit must be less than $5 \%$. Meanwhile, a benchmark of less than $20 \%$ applies to Sharia non-compliant businesses or activities such as stock trading (Zahri, 2020).

\section{Methodology of research}

This research is case study research base on descriptive data. Descriptive data are used to present quantitative descriptions in a manageable form. Descriptive analysis is a fundamental component of this process because of the role it plays in helping us to observe the world or a phenomenon and, subsequently, in identifying research questions and generating hypotheses based on what has been observed (Evergreen, 2013). The data obtained will be analyzed according to the requirements of the study conducted. This method has flexibility and can adapt to changes as the research progresses. The use of such method will lead to further research.

\subsection{CIMB principle asset management as case Study}

CIMB-Principal Asset Management Berhad (CIMB-Principal) is one of the prominent asset management companies that can run regional investment. CIMB-Principal was founded in 1995, and it is one of the biggest asset management companies in Malaysia, and it also runs its operation in Indonesia, Singapura and Thailand.

CIMB-Principal aims to be a renowned investment management company in Southeast Asia by offering a comprehensive range of asset management products. This company runs and distributes a network of comprehensive trust funds, and also, manages flexible portfolios for institution, corporate, government and pension fund. Their regional integrated investment team comprises of a professional and dedicated team, and they are prepared to offer their expertise in equity investment, fixed income, financial management and Shariah-compliant funds management.

CIMB-Principal is co-owned by CIMB Group, one of the most prominent universal banking in Southeast Asia and The Principal Financial Group, U.S.A., one of the global financial companies listed under NYSE, and also, one of the companies listed in the Fortune 500.

\subsection{The analysis on the Islamic Trust Fund in CIMB principle asset management}

The analysis on the Islamic funds under CIMB-Principal Asset Management Berhad was based on five important aspects which are: objective, funds, received a benefit, the strategy for investments, the performance of analyzed funds and the estimation of the fund's investment of the same company, whether investing locally or internationally (Mansor \& Sulaiman, 2009). All of these five aspects were analyzed to prove whether the Islamic based funds have outstanding performances and also, whether these funds are fully compliant with the Shariah principle.

The first aspect that was analyzed is the objective of an introduced trust fund. The objective of the fund is important as it ensures that the investors made the right decision in choosing the right portfolio to invest on. For an Islamic trust fund, this objective will indirectly tell whether the fund is indeed Shariahcompliant or not. When customers were informed on the objectives, they would know whether they would receive their return in the forms of dividends income fund, bond fund or equity fund. The second aspect is 
regarding the specific benefit that the investors would receive if they chose to invest in the fund. Among the benefits are charge, low transaction cost, cooling period and insurance package and takaful.

Furthermore, the third aspect is regarding the analysis of the investment strategy on a certain fund. The investment strategy was identified to determine it as a factor of success. It also depends on the brilliance of the fund management company to manage and to make the correct decision to their funds. Also, the success of a fund is looked at how it manages to achieve its goal or not. The fourth aspect is seen from the performance of the analyzed fund. A good performance will make an Islamic trust fund to be competitive and can yield a great return to its investors. In this sense, a good performance is defined when the performance of the fund outperformed the market return value. Next, the funds are identified to be free of any elements that contradict and oppose the Islamic rule of law. According to Elfakhani et al. (2007), age is an important factor to be considered in measuring the performance of a fund to avoid any survivorship bias. Therefore, only five funds were analyzed in terms of their types of an equity fund and balanced fund. The decision to choose these five funds are due to these funds have invested in the stock market exclusively, and these five funds have their series of records on their returns on investment and the records of their financial fund data. The five funds are CIMB Islamic DALI Equity (CIDE), CIMB Islamic DALI Equity Growth fund (CIDEG), Cimb Islamic Equity Theme (CIDET) fund, CIMB Islamic Balanced fund (CIB), and CIMB Islamic Balanced Growth fund (CIBG).

\subsection{The Analysis of the Performances of the Analyzed funds}

After the analysis was conducted on these funds, which are CIDE fund, CIDEG fund, CIDET fund, CIB fund and CIBG fun, it was found that all of these funds were managed well by CIMB Principal Asset Management Berhad. Looking at the aspect of their investment objectives, the CIDE fund, CIDEG fund, CIDET fund, CIB fund and CIBG fund aim to gain a strong growth on their modal in medium-term length or long term. These funds are invested in numerous main investment portfolios in Malaysia, and these portfolios are Shariah-compliant, and its debt instruments are in line with their investment objectives. In terms of specific benefits, all of these five funds provide the opportunity to invest in either local or regional investment especially in blue-chip investment, growth investment, dividend investment, Islamic debt security and Islamic bond.

Looking at the fund investment strategy, all of these funds have their strategies to ensure that their funds are invested in Shariah-compliant portfolios. The fund investment for equity is made in numerous portfolios listed in the Security Bursa. For the equity investment, such as CIDE fund, CIDEG fund, CIDET fund, CIB fund and CIBG fund, the focus of the investment is prioritized to the portfolios of multiple companies that invest in indexes, luxurious funds, and companies that are rooted in Shariah-compliant growth and listed in the Security Bursa and also selected regional investment such as Hong Kong, Indonesia and South Korea. Companies with good growth records will be chosen to maximize their funds' growth returns. In identifying these companies, these funds will take the initiative to study these companies in terms of their financial growth, industry prospect, the quality of the management, and past companies' records. It was found that the Islamic trust fund under CIMB Principal Asset Management (CPAM) is excellently managed based on their outstanding performances of these five funds. For example, funds like CIDE fund, CIDEG fund, CIDET fund, CIB fund, and CIBG fund always yield the average return that surpassed the KLSI expected return. Referring to Table 1, it was found that for the CIDE fund, the annual average return of the fund since its inception is $214.39 \%$, which surpasses the KLSI average return of $155.62 \%$.

Table 1.The Performance of the fund return since the funds' inception as compared to the KLSI return

\begin{tabular}{|l|c|c|c|c|c|}
\hline & CIDE & CIDEG & CIDET & CIB & CIBG \\
\hline Inception & $214.39 \%$ & $486.03 \%$ & $62.88 \%$ & $159.89 \%$ & $141.42 \%$ \\
\hline FTSE & $155.62 \%$ & $181.99 \%$ & $21.27 \%$ & $98.32 \%$ & $126.95 \%$ \\
\hline
\end{tabular}

Source: Adapted from Master Prospectus (Shariah-Compliant Funds), CIMB Principal Asset Management, 30 Jun 2016

For the CIDEG fund, since its inception, it has yielded a return that surpasses the KLSI benchmark, which was recorded at $486.03 \%$, as compared to the KLSI return of $181.99 \%$. The CIDET fund also showed a return value that surpasses the KLSI return, which is $21.27 \%$. For the $\mathrm{CIB}$ fund, the return also surpasses 
KLSI by $159.89 \%$, compared to KLSI referral of $98.32 \%$. For the CIBG fund, it was found that the performance also surpasses KLSI referral of $141.42 \%$, compared to KLSI of $126.95 \%$.

Table 2. The average annual fund returns for CIDE, CIDEG, CIDET, CIB and CIBG funds for the end year of June 30th 2016

\begin{tabular}{|c|c|c|c|c|}
\hline $\begin{array}{c}\text { The types of } \\
\text { funds }\end{array}$ & Applied benchmark & Year 1 & Year 3 & Year 5 \\
\hline CIDE & $\begin{array}{l}\text { 70\% FTSE Bursa Malaysia } \\
\text { EMAS Shariah Index }+30 \% \\
\text { MSCI AC Asia ex Japan Islamic Index }\end{array}$ & -1.15 & 13.57 & 31.85 \\
\hline CIDEG & FTSE Bursa Malaysia EMAS Shariah Index & -0.21 & 6.95 & 35.33 \\
\hline CIDET & FTSE Bursa Malaysia EMAS Shariah Index & -2.29 & 6.85 & 28.25 \\
\hline $\mathrm{ClB}$ & $\begin{array}{l}\text { 30\% FTSE Bursa Malaysia EMAS Shariah Index }+30 \% \\
\text { MCSI AC Asia ex Japan Islamic Index }+40 \% \text { CIMB } \\
\text { Islamic 1-month General Investment Account-I (GIA) }\end{array}$ & 0.27 & 18.02 & 28.07 \\
\hline CIBG & $\begin{array}{l}\text { 60\% FBM EMAS Shariah Index }+40 \% \text { CIMB Islamic 1- } \\
\text { Month General Investment Account-I (GIA) }\end{array}$ & 0.86 & 9.83 & 29.58 \\
\hline
\end{tabular}

Source: Adapted from Master Prospectus (Shariah-Compliant Funds), CIMB Principal Asset Management, 30 Jun 2016

Table 2 refers to the performance of the fund return for all analyzed funds, CIDE, CIDEG, CIDET, CIB and period end of June 31st 2016. It was found that except for CIB fund, the other funds yielded good return in one-year period. This was due to the other funds exceed the set benchmark of $0.71 \%$, except for $\mathrm{CIB}$, which was set at $0.27 \%$. For the three-year period and the five-year period, all funds recorded increased return. According to Shafee (2018), there is a significant impact between pass performance and mutual fund and investment decision making.

In terms of the distribution of the funds, all of the distributions are made in both local and international companies, and all of them were approved by the Shariah advisor and these companies have the potential to produce a high return. Table 8.3 shows the list of companies for the fund's distribution for Islamic trust funds.

Table 3. The list of Companies for the distribution of investment in the Islamic Trust Fund under CIMB Principal Asset Management

\begin{tabular}{|l|l|l|}
\hline \multirow{3}{*}{ Year } & \multicolumn{2}{|c|}{ Name of the Companies } \\
\cline { 2 - 3 } & \multicolumn{2}{|c|}{ Local and International Investment Companies } \\
\hline \multirow{4}{*}{2015} & $\begin{array}{l}\text { 1. Axiata Group Bhd } \\
\text { 2. Bumitama Agri Ltd }\end{array}$ & 13. MISC Bhd \\
& 3. Digi.com Bhd & 14. Nestle Malaysia Bhd \\
& 4. First Resources Ltd & 16. Perbadanan Kemajuan N.Selangor \\
& 5. Fraser \& Neave HIdg Bhd & 17. Petronas Gas Bhd \\
& 6. Gamuda Bhd & 18. Sime Darby Bhd \\
& 7. Golden Asset Intl Fin Ltd & 19. Telekom Malaysia Bhd \\
& 8. IHH Healthcare Bhd & 20. Telekomunikasi TBK Bhd \\
& 9. IJM Corp Bhd & 21. Tenaga Nasional Bhd \\
& 10. IOl Corp Bhd & 22. Westports HIdgs Bhd \\
& 11. Jimah Energy Ventures & 23. Tencent HIdg Ltd (Hong Kong) \\
12. Malakoff Power Bhd & 24. Amorepacific Corp (South Korea) \\
\hline
\end{tabular}

The Islamic Trust Fund is a type of collective fund that is offered and managed by Professional Fund Management (FIMM, 2005). It is expected to give returns for investors in the long term. A fund is considered as an Islamic fund when it agreed with the Shariah principle, and the investment was made in the secured portfolios that have attained the Shariah-compliant status (Wan Azman Wan Hassan, 2012).

\section{Conclusions}

Based on the analysis of this chapter, it was found that all five analyzed funds, which are CIDE fund, CIDEG fund, CIDET fund, $\mathrm{CIB}$ fund, and, CIBG fund are complying with the principal concept of Islamic 
investment. All of these funds are invested in Shariah-compliant trust fund, and they are following the guidelines that are set by the Shariah Advisory Council (SAC). The applied Shariah principles are almusyarakah principle, al wakalah, al-ujr, harta musya, and 'uqud ghayr musmma also, the applied the added Shariah principle of ta'widh and $i b r a^{\prime}$. The existence of a governing body such as SAC in CIMB Principal Asset Management Berhad has played a crucial role in ensuring that the operations of the Islamic funds are complying with the Shariah principles. SAC is paramount to determine the legitimacy of these Islamic funds, even though these funds are managed by conventional companies.

Therefore, the Islamic trust fund is one of the productive instruments that offered a moderate return to investors with minimal risk. This is seen by the analysis that found that the return of the investment exceeds the average annual return in the three-year period and above. Also, the features of Islamic fund are collective investments that offer the investors a chance to invest in numerous Shariah-compliant portfolios, have moderate risk and managed professionally. It is complying with the Shariah principles. Also, these funds are managed by a management company with high caliber. In long terms, the Islamic trust fund is seen as a high potential and stable investment in generating and building a strong and competitive Islamic economy. This type of investment should be grasped by Islamic investors, especially those who are involved and active in Islamic trust funds.

\section{References}

1. Dana unit amanah di Malaysia- Ringkasan Statistik. (2015). Suruhanjaya sekuriti Malaysia. Access from http: //www.sc.com.my/data-statistics/ unit-trust-funds-in-malaysia-Summary-of-statistics/

2. Elfakhani, S. M., Hassan, M. K., \& Sidani, Y. M. (2007). 16 Islamic mutual funds. Handbook of Islamic banking, 256.

3. Evergreen, S. D. (2017). Presenting data effectively: Communicating your findings for maximum impact. Sage Publications.

4. Mansor, F., \& Sulaiman, F. (2009). Operasi dana saham amanah secara Islam: kajian kes di Public Mutual Berhad. Jurnal Syariah, 17(1), 69-88.

5. Federation of Investment Managers Malaysia (FIMM). (2005). Federation of Investment Manager Malaysia (FIMM). Kuala Lumpur: Urusniaga Niaga Unit Amanah.

6. Majlis Penasihat Shariah Suruhanjaya Sekuriti. (2012). Keputusan Majlis Penasihat Shariah Suruhanjaya Sekuriti Malaysia, Suruhanjaya Sekuriti Malaysia. Diakses daripada http://www.cimbprincipal.com.my.

7. Norhafiza, B. D. (2006). Perkembangan Saham Amanah Islam Dan Konvensional di Malaysia: Kajian Terhadap Beberapa Dana Terpilih, Latihan Ilmiah, Akademik Pengajian Islam, Universiti Malaya, Kuala Lumpur.

8. Shafee, N. B. (2018). Mutual fund investment decision by Malaysian investor. International Journal of Academic Research in Business and Social Sciences, 8, 607-12.

9. Zahri, M. A. (2016). Dimensi kepatuhan beragama dalam gelagat pemilihan dana Amanah Islam (DAI): Satu sorotan awal, Paper presented at Workshop Antarabangsa Pembangunan Islam (WAPI 2016), Universitas Muhammadiyah Sumatera (UMSU), Medan, Indonesia.

10. Zahri, M. A., Melzatia, S., Sari, M. D., \& Yahaya, S. (2020). Awareness and Marketing in Islamic Unit Trust Fund Investment among Muslim Investors. Talent Development \& Excellence, 12(1), 3448-3463. 